\title{
THE INFLUENCE OF ELECTROMAGNETIC FIELD ON MORPHO- PHYSIOLOGICAL PARAMETERS OF BACTERIAL CELLS EVALUATED THROUGH FLOW CYTOMETRY
}

\author{
E. Radu ${ }^{1}$, F. Marinescu ${ }^{2}$, I. Savin², C.M. Kamerzan (Saviuc) ${ }^{3}$, M. Bădic ${ }^{1}$, C. Chifiriuc ${ }^{3}$
}

IINCDIE ICPE-CA, 313 Splaiul Unirii, Bucharest, Romania elena.radu@icpe-ca.ro ; mihai.badic@icpe-ca.ro

${ }^{2}$ National Institute for Research and Development in Environmental Protection INCDPM, Bucharest, Romania.

${ }^{3}$ Research Institute of the University of Bucharest - ICUB, University of Bucharest, 9195 Splaiul Independentei, Bucharest, Romania.

\begin{abstract}
Flow cytometry represents an important tool in environmental biology, and especially in cellular biology, through its ability to distinguish among different physiological states (viable, latent and non-viable). Flow cytometry combined with fluorescent markers, such as propidium iodide and ethidium bromide allows to perform rapid measurements on individual cells and also simultaneous measurements of multiple cellular parameters, both structural and functional.

The aim of this paper was to investigate the influence of the electromagnetic field on the morpho-physiological parameters of some bacterial strains cells isolated from wastewater, assessed through flow cytometry. In this respect, a number of 10 bacterial strains isolated from wastewater (E. coli, Salmonella sp., Enterobacter sp., Citrobacter sp., Klebsiella sp. and Enterococcus sp.) were exposed to an electromagnetic field $(50 \mathrm{~Hz}$ electric field at different voltages) for 24 hours, at $37^{\circ} \mathrm{C}$. Both samples, the ones exposed to electromagnetic field and blank samples (unexposed) were assessed by flow cytometry technique. Two possible mechanism of action have been tracked, i.e. the efflux pumps activity (fluorescence marker Ethidium Bromide) and permeabilisation of cellular layers (fluorescence marker - Propidium lodide). Both mechanisms of action have been identified, from slightly to significant modifications, as compared to untreated controls, quantified as $\triangle \mathrm{MFI}$ (median of fluorescence intensity). Conclusion: Our results suggest that flow cytometry could be used for the real-time evaluation of the influence of different electromagnetic fields on the aquatic microbiota, the obtained results being of great interest for the development of technological solution with increased efficiency in the (waste)water treatment.
\end{abstract}

Keywords: bacteria, electromagnetic field, flow-cytometry, fluorescent dyes, wastewater.

\section{Introduction}

In the least 20 years, flow cytometry became an important tool for microbiological studies, especially in biotechnological processes, food microbiology and chemical sterilization processes (1-5).

Flow cytometry makes possible the fast measurements of single cells in homogeneous or heterogeneous populations, providing data for multiple parameters, both structural and functional (6). These measurements are usually based on light scattering or fluorescence. A membrane impermeant fluorescent probe that can passively diffuse through the cell wall of a bacterium can act as an indicator of a loss in membrane integrity (6) and of cellular viability. Different studies were reported regarding the analysis of the membrane integrity based on the capacity of the cells to exclude 
different compounds, such as fluorescent dyes: Porpidium lodide-PI (7), Ethidium Bromide-EB (8), Ethidium-monoazide-EMA (9), Fluorescein diacetate-FDA (10); these dyes used in low concentrations do not cross the cellular membrane in normal conditions. The use of flow cytometry in the fast in situ analysis of single cells and in combination with different staining techniques (for example live/dead staining) could offer important conclusions, both quantitative and qualitative $(11-13,6)$.

FDA is usually used to detect viable bacteria (14-16). The evaluation of microbial viability represents an important requirement in different areas of microbiology, such as health, biotechnologies, food technologies, water industry and pharmaceutical industries (17-21). The ability to distinguish between different physiological states (viable, latent, non-viable) represents an important tool, especially for the evaluation of survival rates of pathogenic microorganisms (22), of the growth and development of microorganisms in oligotrophic environments (723 and of the effect of toxic substances on microbial activity (24).

Flow cytometry play an important role in environmental microbiology, by combining fast and direct methods to determine the number of cells and the distribution size, singlecells biochemical and physiological characteristics, thus revealing the presence of the heterogeneity of microorganisms in populations and communities (25-27). Various studies have been published on flow cytometry applications in environmental microbiology (28-29). Combining the flow cytometry with different fluorescent dyes has become an useful approach for the study of activated sludge used in the wastewater treatment processes and for the microbiological analysis of drinking water (30-34).

It is expected that flow cytometry will revolution the microbiology in the future through understanding the complexity of microbial ecosystems and how they work and will aid the researchers to isolate some microorganisms uncharacterized until now (34).

The aim of this paper was to investigate the influence of the electromagnetic field on morpho-physiological parameters of some bacterial strains isolated from wastewater, assessed through flow cytometry. The main objective of this study was to investigate if the electromagnetic fields affect the membrane integrity of bacterial strains isolated from wastewater, through flow cytometry combined with fluorescent dyes, such as PI and EB.

\section{Materials and methods}

A number of 10 bacterial strains isolated from wastewater were investigated. The laboratory code, isolation sites and taxonomic affiliation are summarized in Table 1.

Table 1. Investigated bacterial strains

\begin{tabular}{|c|c|c|c|}
\hline No. & ID & Bacterial strains & Origin \\
\hline 1. & S18 & Salmonella arizonae & Sewage water \\
\hline 2. & P34 & Klebsiella sp. & Treated wastewater Bucharest \\
\hline 3. & S11 & Salmonella sp. & Sewage water \\
\hline 4. & N85 & $\begin{array}{c}\text { Enterobacter } \\
\text { agglomerans }\end{array}$ & Wastewater Fundeni Hospital \\
\hline 5. & N61 & Escherichia coli & Wastewater Fundeni Hospital \\
\hline 6. & N60 & Citrobacter farmeri & Wastewater Fundeni Hospital \\
\hline 7. & N67 & Klebsiella oxytoca & Wastewater Fundeni Hospital \\
\hline 8. & O19 & Enterobacter $s p$. & Domestic wastewater Bucharest \\
\hline 9. & P62 & Enterococcus $s p$. & Treated wastewater Bucharest \\
\hline 10. & R73 & Enterococcus $s p$. & Dambovita river water Bucharest \\
\hline
\end{tabular}


The bacterial strains were grown in Petri plates with Mueller-Hinton agar and they were exposed to an electromagnetic field of $50 \mathrm{~Hz}$ at different voltages (Table 2):

Table 2. Bacterial strains laboratory code and the type of the applied electric field

\begin{tabular}{|c|c|}
\hline Bacterial strains & Voltage \\
\hline N61 - N67 & $217 \mathrm{~V}$ \\
\hline S11 - S18 & $420 \mathrm{~V}$ \\
\hline P34 - R73 & $665 \mathrm{~V}$ \\
\hline O19 - P62 & $875 \mathrm{~V}$ \\
\hline N60 - N85 & $1120 \mathrm{~V}$ \\
\hline
\end{tabular}

The bacterial strains were placed in an incubator for 24 hours at $35 \pm 2^{\circ} \mathrm{C}$ in an electrical installation (for obtaining a homogeneous electric field). Control and exposed bacterial cultures were harvested and used to prepare bacterial suspensions of $0.5 \mathrm{McF}$ arland density; prior to the flow cytometry analysis the bacterial cells were separated by centrifugation (at $13.000 \mathrm{G}$ for 3 minutes), washed three times with sterile distilled water and stained with $0.3 \mu \mathrm{PI}$ (Propidium lodide) and EB (Ethidium Bromide) and incubated in the dark for 15 minutes before measurements.

\section{Results and discussions}

The flow cytometry analysis of of the electromagnetic field mechanism of action on the tested bacteria proved to be strain specific. Both cellular wall permeabilization as well as efflux pump activity inhibition were revealed.

The electromagnetic field did not influence the S11 and N61 tested strains (Table 3). In exchange, the N60 strain showed an increase of median of fluorescence intensity (MFI), suggesting the efflux pumps overexpression, even when the highest voltage has been applied (Fig. 1). This suggests that the presence of electromagnetic fields could activate in some cases, the efflux pumps and therefore increase the microbial resistance to antibiotics and other antimicrobial agents.
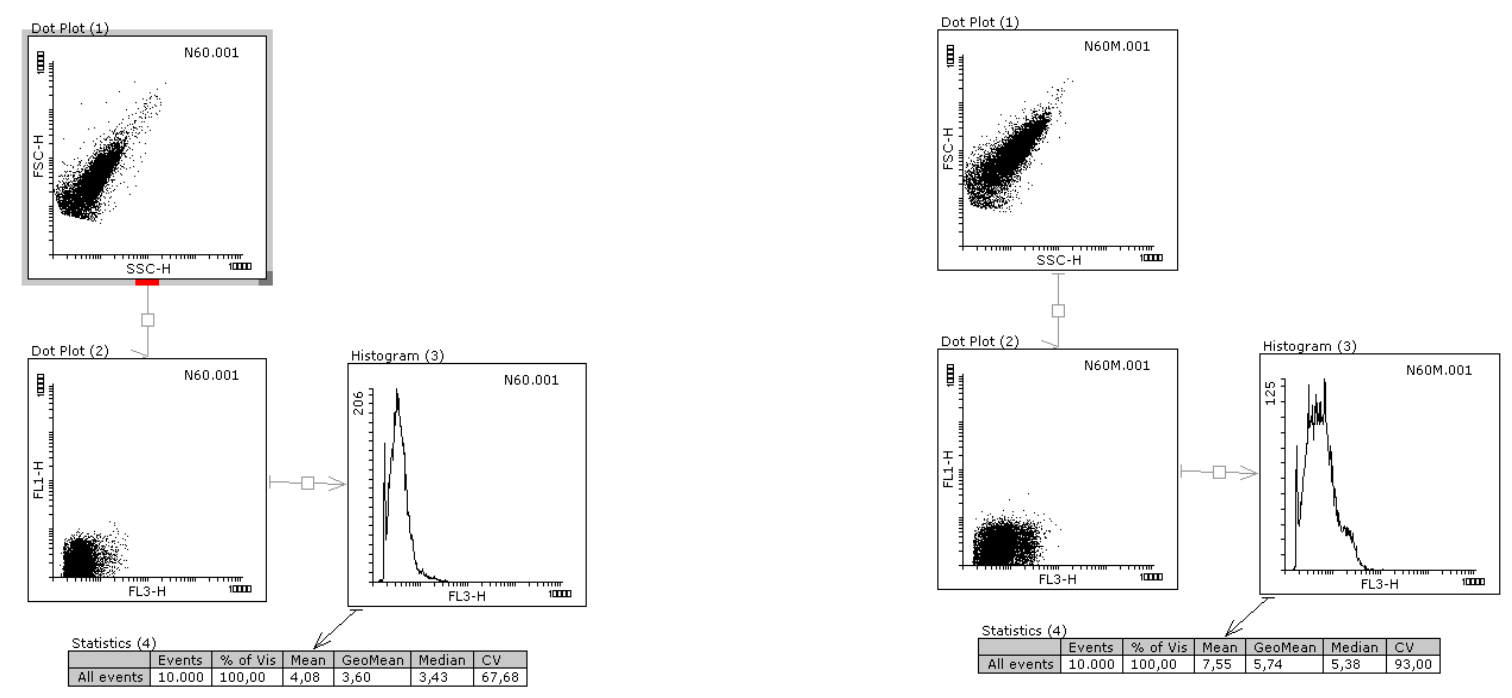

Fig. 1 Dot plot and histograms for the N60 sample PI labeled 

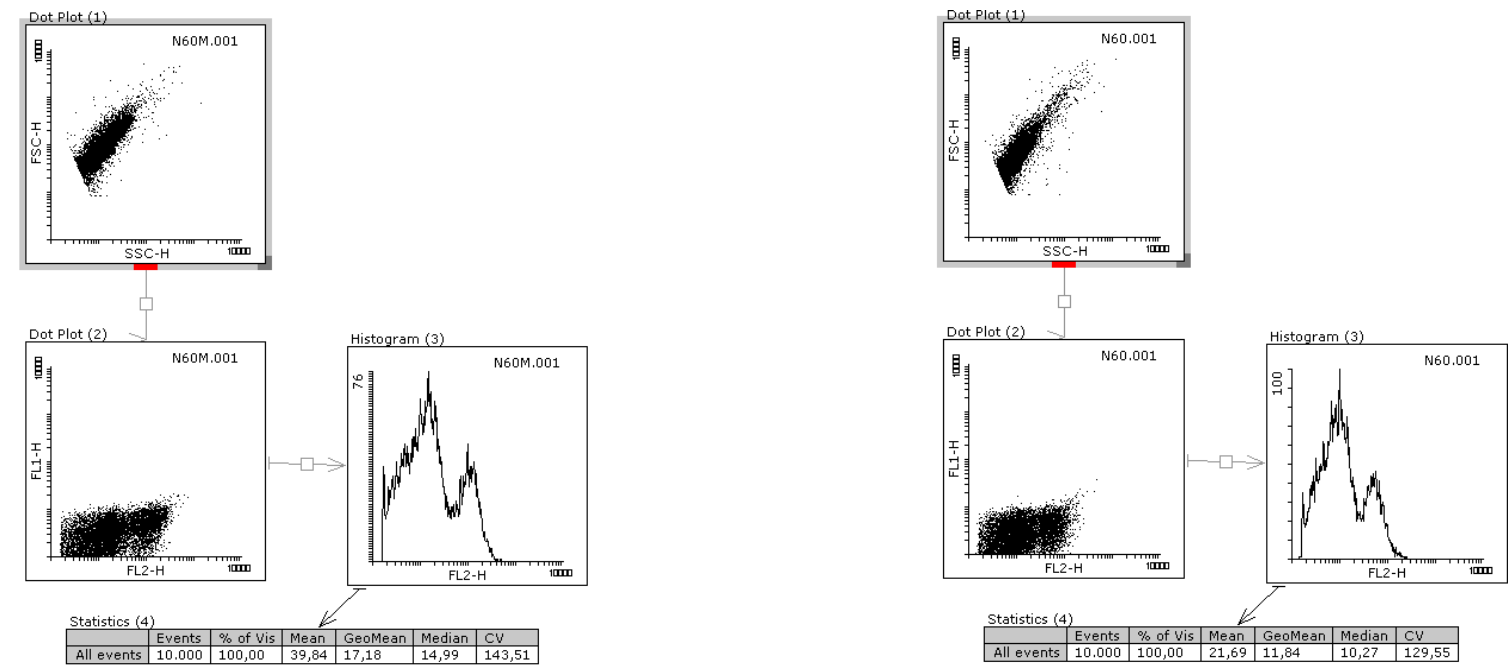

Fig. 2 Dot plot and histograms for the $N 60$ sample EB labeled

Table 3. Raw data for median of fluorescence intensity

\begin{tabular}{|c|c|c|c|c|c|c|}
\hline \multirow{3}{*}{ No. } & \multirow{3}{*}{ ID } & \multicolumn{4}{|c|}{ MFI } & \multirow{3}{*}{$\begin{array}{c}\text { Identified } \\
\text { mechanism }\end{array}$} \\
\hline & & \multicolumn{2}{|c|}{ PI } & \multicolumn{2}{|c|}{ EB } & \\
\hline & & Exposed & Control & Exposed & Control & \\
\hline 1. & S18 & 3.59 & 3.4 & 8.58 & 6.92 & slight EPI \\
\hline 2. & P34 & 3.96 & 4.03 & 54.55 & 38.25 & EPI \\
\hline 3. & R73 & 3.43 & 3.22 & 106.5 & 72.99 & EPI \\
\hline 4. & N85 & 3.65 & 3.25 & 47.4 & 33.98 & EPI \\
\hline 5. & N61 & 3.25 & 3.49 & 35.23 & 38.2 & $\mathrm{NI}$ \\
\hline 6. & N60 & 3.43 & 5.38 & 10.27 & 14.99 & EPS \\
\hline 7. & N67 & 7.77 & 5.57 & 51.4 & 45.73 & $\mathrm{CC}$ \\
\hline 8. & 019 & 4.91 & 3.31 & 12.59 & 8.9 & EPI \\
\hline 9. & P62 & 3.42 & 3.59 & 23.28 & 21.1 & slight EPI \\
\hline 10. & S11 & 3.52 & 3.16 & 6.73 & 6.38 & $\mathrm{NI}$ \\
\hline
\end{tabular}

EPI - efflux pumps inhibition, $\mathrm{NI}$ - no inhibition, EPS - efflux pumps over-expression

For the rest of the strains, an inhibition of the efflux pumps activity, which could be correlated with an increase of microbial susceptibility to different antimicrobial substances could be observed. The best EPI activity was induced by the 635V electromagnetic field in the case of Klebsiella sp. and Enterococcus sp. strains.

\section{Conclusions}

The exposure of bacterial strains isolated from wastewater to different electromagnetic fields was accompanied by changes in the membrane permeability and efflux pumps activity. However, further analyses are needed for optimizing the exposure parameters (time and/ or the voltage applied), in order to be able to formulate potential applications of the electromagnetic field to positively manipulate the wastewater microbiota. 


\section{Acknowledgements}

This work was financiary suported by National Project no. 161103 01/2016 and the research project PN-II-RU-TE- 2014-4-2037 from the Romanian National Authority of Scientific Research and Inovation.

\section{References:}

1. Berney M., H. U. Weilenmann, T. Egli, (2006), Flow-cytometric study of vital cellular functions in Escherichia coli during solar disinfection (SODIS), Microbiology, 152, 1719-1729.

2. Hewitt C. J., G. Nebe-Von Caron A. W. Nienow, C. M. McFarlane, (1999), Use of multistaining flow cytometry to characterise the physiological state of Escherichia coli W3110 in high cell density fed-batch cultures, Biotechnology Bioengineering, 63, 705-711.

3. Joux F., P. Lebaron, (2000), Use of fluorescent probes to assess physiological functions of bacteria at single-cell level, Microbes Infection, 2, 1523-1535.

4. Nebe-von-Caron G., P. J. Stephens, C. J. Hewitt, J. R. Powell, R. A. Badley, (2000), Analysis of bacterial function by multi-colour fluorescence flow cytometry and single cell sorting, Journal Microbiological Methods, 42, 97-114.

5. Porter J., D. Deere, M. Hardman, C. Edwards, R. Pickup, (1997), Go with the flow cytometry in environmental microbiology, Microbiology Ecology, 24, 93-101.

6. Vital M, Fuchslin HP, Hammes F, Egli T., (2007), Growth of Vibrio cholera O1 Ogawa Eltor in freshwater, Microbiology, 153, 1993- 2001.

7. Berney M, Hammes F, Bosshard F, Weilenmann HU, Egli T, (2007), Assessment and interpretation of bacterial viability by using the LIVE/DEAD BacLight Kit in combination with flow cytometry, Applied Environmental Microbiology, 73, 3283-3290.

8. Hiraoka Y, Yamada T, Tone K, Futaesaku Y, Kimbara K., (2002), Flow cytometry analysis of changes in the DNA content of the polychlorinated biphenyl degrader Comamonas testosterone TK102: effect of metabolites on cell-cell separation, Applied Environmental Microbiology, 68, 5104-5112.

9. Mason C. A., G. Hamer, J. D. Bryers, (1986), The death and lysis of bacteria in environmental processes, Microbiology Revue, 39, 373-401.

10. Hewitt C. J., G. Nebe-Von-Caron, (2004), The application of multiparameter flow cytometry to monitor individual microbial cell physiological state, Advanced Biochemistry Engineering Biotechnology, 89, 197-223.

11. Looser V., F. Hammes, M. Keller, M. Berney, K. Kovar, T. Egli, (2005), Flow-cytometric detection of changes in the physiological state of $E$. coli expressing a heterologous membrane protein during carbon-limited fedbatch cultivation, Biotechnology Bioengineering, 92, 69-78.

12. Boulos L., M. Prevost, B. Barbeau, J. Coallier, R. Desjardins, (1999), LIVE/DEAD BacLight: application of a new rapid staining method for direct enumeration of viable and total bacteria in drinking water, Journal Microbiological Methods, 37, 77-86.

13. Hoefel D., W. L. Grooby, P. T. Monis, S. Andrews, C. P. Saint, (2003), Enumeration of water-borne bacteria using viability assays and flow cytometry: a comparison to culture-based techniques, Journal Microbiological Methods, 55, 585-597.

14. Shapiro H. M., (1988), Practical flow cytometry, Liss, New York.

15. Pyle B. H., S. C. Broadaway, G. A. McFeters, (1999), Sensitive detection of Escherichia coli $0157: \mathrm{H} 7$ in food and water by immunomagnetic separation and solid-phase laser cytometry, Applied Environmental Microbiology, 65, 1966-1972.

16. Vasavada P. C., C. H. White, (1993), Symposium: developing methodology for microbial evaluation of milk and dairy products, Journal Dairy Science, 76, 3099-3100.

17. Verthe K., W. Verstraete, (2006), Use of flow cytometry for analysis of phage-mediated killing of Enterobacter aerogenes, Research Microbiology, 157, 613-618. 
18. Crissman H. A., J. A. Steinkamp, (1990), Cytochemical techniques for multivariate analysis of DNA and other cellular constituents, 227-247 In M. R. Melamed, T. Lindmo, M. L. Mendelsohn (ed.), Flow cytometry and sorting. Wiley-Liss, New York.

19. Horan P. K., J. N. Kappler, (1977), Automated fluorescence analysis for cytotoxicity assays, Journal Immunological Methods, 18, 309-316.

20. Hixon S. C., W. E. White, K. L. Yielding, (1975), Selective covalent binding of an ethidium analogue to mitochondrial DNA with production of petite mutants in yeast by photoaffinity labeling, Journal Molecular Biology, 92, 319-329.

21. Haugland P. H., (1992), Molecular probes: handbook of fluorescent probes and research chemicals. Molecular Probes, Inc., Eugene, Oregon.

22. Chrzanowski T. H., R. D. Crotty, J. G. Hubbard, R. P. Welch, (1984), Applicability of the fluorescein diacetate method of detecting active bacteria in freshwater, Microbiology Ecology, 10, 179-185.

23. Diaper J. P., C. Edwards, (1994), The use of fluorogenic esters to delete viable bacteria by flow cytometry, Journal Applied Bacteriology, 77, 221-228.

24. Diaper J. P., K. Tither, C. Edwards, (1992), Rapid assessment of bacterial viability by flow cytometry, Applied Microbiology Biotechnology, 38, 268-272.

25. Robinson J.P., (1999), Current Protocols in Cytometry, John Wiley and Sons, New York.

26. Shapiro H.M., (1995), Practical Flow Cytometry, 3rd edition., 412-425, John Wiley and Sons, New York.

27. Porter J., Deere D., Pickup R., Edwards C., (1996), Fluorescent probes in flow cytometry: new insights into environmental bacteriology, Cytometry, 23, 91-96.

28. Davey H.M., Kell D.B., (1996), Flow cytometry and cell sorting of heterogeneous microbial populations: the importance of single-cell analyses, Microbiology Revue, 60, 641696.

29. Porter J., Deere D., Hardman M., Edwards C., Pickup R., (1997), Go with the low use of flow cytometry in environmental microbiology, Microbiology Ecology, 24, 93-101.

30. Falcioni T. et al., (2006), Comparison of disruption procedures for enumeration of activated sludge floc bacteria by flow cytometry, Cytometry B Clinical Cytometry, 70B, 149153.

31. Foladori P. et al., (2007), Effects of sonication on bacteria viability in wastewater treatment plants evaluated by flow cytometry-fecal indicators, wastewater and activated sludge, Water Research, 41, 235-243.

32. Hammes F. et al., (2008), Flow-cytometric total bacterial cell counts as a descriptive microbiological parameter for drinking water treatment processes, Water Research, 42, 269277.

33. Hammes F.A., Egli T., (2005), New method for assimilable organic carbon determination using flow-cytometric enumeration and a natural microbial consortium as inoculum, Environmental Science Technology, 39, 3289-3294.

34. Czechowska K., Johnson D. R., van der Meer J. R., (2008), Use of flow cytometric methods for single-cell analysis in environmental microbiology, Current Opinion in Microbiology, 11, 205-212. 